\title{
External cues to drive B cell function towards immunotherapy
}

\section{Review Article}

\section{Author(s):}

Stoycheva, Diana; Simsek, Hasan; Weber, Willi; Hauser, Anja E.; Klotzsch, Enrico (D)

Publication date:

2021-10-01

Permanent link:

https://doi.org/10.3929/ethz-b-000471643

\section{Rights / license:}

Creative Commons Attribution-NonCommercial-NoDerivatives 4.0 International

\section{Originally published in:}

Acta Biomaterialia 133, https://doi.org/10.1016/j.actbio.2021.02.026 
Review article

\title{
External cues to drive B cell function towards immunotherapy ${ }^{\sqrt[1]{4}}$
}

\author{
Diana Stoycheva ${ }^{a}$, Hasan Simsek ${ }^{b}$, Willi Weber ${ }^{\mathrm{b}}$, Anja E. Hauser ${ }^{\mathrm{c}, \mathrm{d}}$, Enrico Klotzsch ${ }^{\mathrm{a}, \mathrm{b}, *}$ \\ a Laboratory of Applied Mechanobiology, Department for Health Sciences and Technology, ETH Zürich, Zürich, Switzerland \\ ${ }^{\mathrm{b}}$ Institute for Biology, Experimental Biophysics/Mechanobiology, Humboldt University of Berlin, Berlin, Germany \\ ' Immunodynamics, Deutsches Rheuma-Forschungszentrum Berlin, A Leibniz Institute, Berlin, Germany \\ ${ }^{\mathrm{d}}$ Department of Rheumatology and Clinical Immunology, Charité-Universitätsmedizin Berlin, Berlin, Germany
}

\section{A R T I C L E I N F O}

\section{Article history:}

Received 27 October 2020

Revised 1 February 2021

Accepted 17 February 2021

Available online 23 February 2021

\section{Keywords:}

B cell activation

Adoptive immunotherapy

B cell-targeted therapy

B-cell maturation

B cell tumor immunity

Autoimmunity

\begin{abstract}
A B S T R A C T
Immunotherapy stands out as a powerful and promising therapeutic strategy in the treatment of cancer, infections, and autoimmune diseases. Adoptive immune therapies are usually centered on modified $\mathrm{T}$ cells and their specific expansion towards antigen-specific T cells against cancer and other diseases. However, despite their unmatched features, the potential of B cells in immunotherapy is just beginning to be explored. The main role of B cells in the immune response is to secrete antigen-specific antibodies and provide long-term protection against foreign pathogens. They further function as antigen-presenting cells (APCs) and secrete pro- and anti-inflammatory cytokines and thus exert positive and negative regulatory stimuli on other cells involved in the immune response such as $\mathrm{T}$ cells. Therefore, while hyperactivation of B cells can cause autoimmunity, their dysfunctions lead to severe immunodeficiencies. Only suitably activated B cells can play an active role in the treatment of cancers, infections, and autoimmune diseases. As a result, studies have focused on B cell-targeted immunotherapies in recent years. For this, the development, functions, interactions with the microenvironment, and clinical importance of B cells should be well understood. In this review, we summarize the main events during B cell activation. From the viewpoint of mechanobiology we discuss the translation of external cues such as surface topology, substrate stiffness, and biochemical signaling into B cell functions. We further dive into current B cell-targeted therapy strategies and their clinical applications.
\end{abstract}

\section{Statement of significance}

B cells are proving as a promising tool in the field of immunotherapy. B cells exhibit various functions such as antibody production, antigen presentation or secretion of immune-regulatory factors which can be utilized in the fight against oncological or immunological disorders. In this review we discuss the importance of external mechanobiological cues such as surface topology, substrate stiffness, and biochemical signaling on B cell function. We further summarize B cell-targeted therapy strategies and their clinical applications, as in the context of anti-tumor responses and autoimmune diseases.

(C) 2021 Acta Materialia Inc. Published by Elsevier Ltd. This is an open access article under the CC BY-NC-ND license (http://creativecommons.org/licenses/by-nc-nd/4.0/)

\section{B cell activation}

The immune system is a complex platform that creates protection against foreign pathogens and formation of tumors. The components of the adaptive immune response operate in a highly co-

\footnotetext{
Part of the Special Issue on Immunomodulatory Biomaterials, guest-edited by Professor Georg Duda and Doctor Taimoor Qazi.

* Corresponding author.

E-mail address: enrico.klotzsch@hu-berlin.de (E. Klotzsch).
}

ordinated manner to ensure specific and long-lasting protection. This protection is mediated by the concerted action of $\mathrm{B}$ and $\mathrm{T}$ lymphocytes. While $\mathrm{T}$ cells recognize and kill infected or altered cells, B cells act as antigen-presenting cells (APCs) to T cells, and can produce antibodies that can recognize both free or membrane bound antigens [1,2]. Owing to this function, B cells are a main target to the development of vaccine approaches and autoimmune therapies [3,4] and their products, antibodies, are widespread tools used in disease prevention, therapy, diagnosis as well as research (see Fig. 1A, C). 


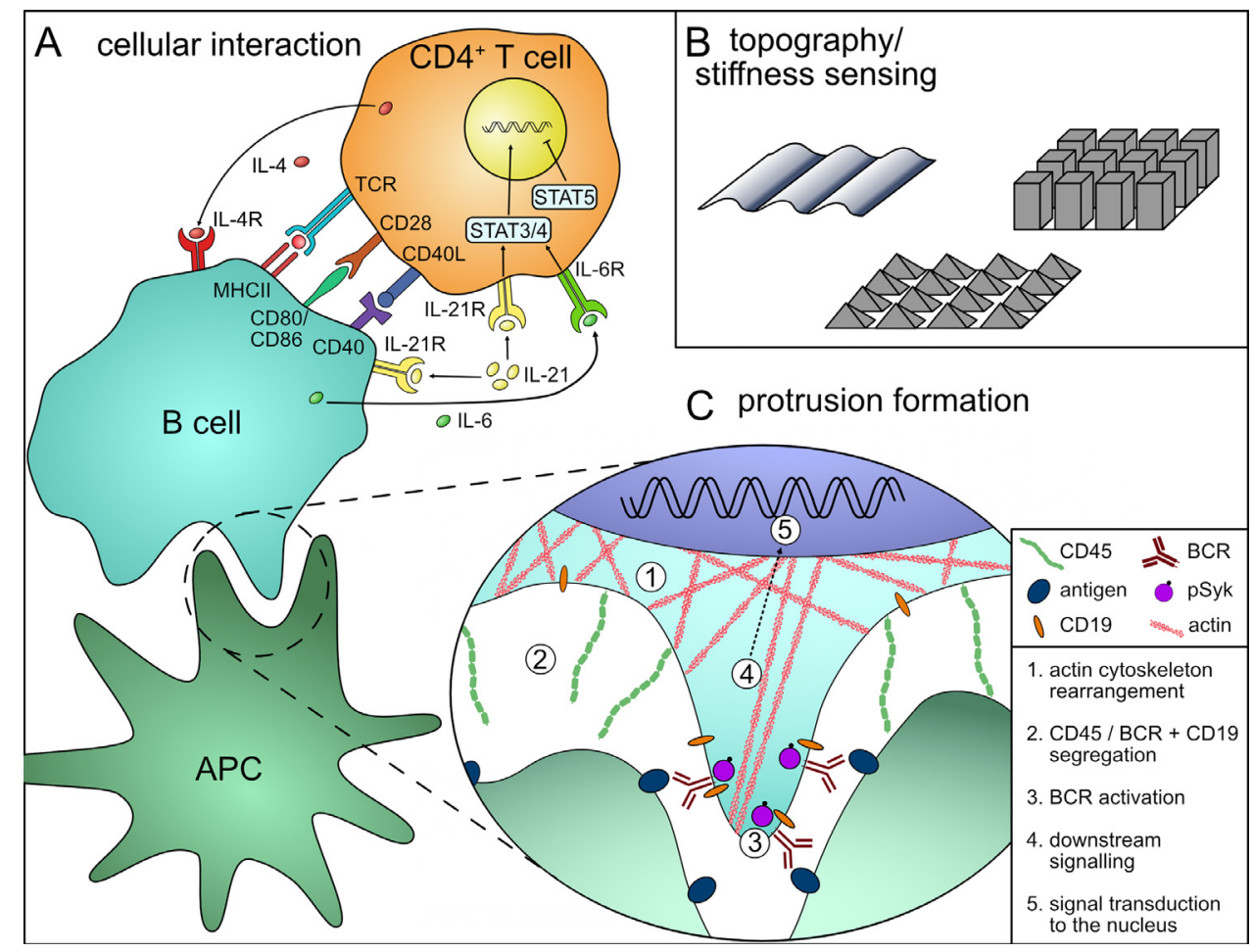

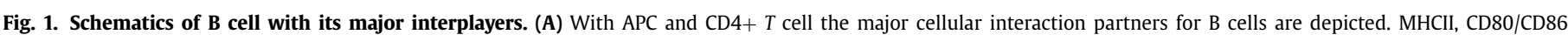

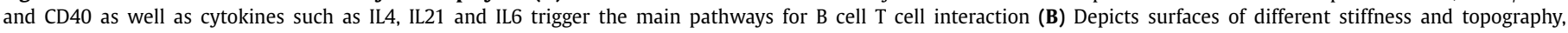
facilitating different B cell pathways. (C) B cells form protrusion to enhance stimulatory and regulatory effects.

The $B$ cell response undergoes several stages to cover the full spectrum of $B$ cell-mediated protection. The encounter of a foreign antigen with a naive $B$ cell via its $B$ cell receptor (BCR) initiates a very dynamic process of activation.

B cells can recognize both soluble as well as surface-bound antigens presented by antigen-presenting cells (APCs), such as marginal zone macrophages [5], dendritic cells (DCs) [6,7] or bound in the form of immune complexes on the surface of follicular dendritic cells (FDCs) [8-10], stromal cells specialized for long-term retention of antigens in B cell follicles within secondary lymphoid organs [11]. Depending on its properties, an antigen can activate a $B$ cell in a soluble, multimerized or membrane-bound form. Most B cell activation protocols use soluble antigens and adjuvants. Yet, soluble antigens provide no resistance thus require a higher abundance and threshold for activation. On the other hand, capture and presentation of membrane-bound antigen from a noninternalizable surface depends on antigen-BCR affinity over a wide affinity range and generally requires lower threshold for activation [12]. Antigen recognition involves restructuring of actin cytoskeleton and rearrangement of surface molecules, formation of a specialized intercellular contact called the immunological synapse (IS), downstream BCR signaling and internalization, processing and presentation of the BCR-bound antigen on major histocompatibility complex II (MHCII) molecules [13-16]. In addition to direct BCR engagement through soluble, multivalent and membrane-bound antigens, there is increasing evidence that the surface topology and the actin cytoskeleton contribute to the formation of microclusters and IS [16-22].

Naive B cells can take on different fates, fulfilling their specialized roles. Plasma cells differentiate from activated B cells, either in extrafollicular responses [23] or during germinal center reactions [24], which constitute specialized microenvironments for class switch recombination and somatic hypermutation, the latter being crucial for affinity maturation of the humoral immune response. It was initially proposed that extrafollicular plasma cells, which constitute a fast, T-independent first line of response, are generally short lived and die within a few days. However, several more recent reports have shown that T-independent antigens, which fail to induce productive germinal centers, are actually able to induce the migration of newly generated plasma blasts to the bone marrow [25-27]. These antigens include pathogenassociated molecular patterns (PAMPs), which induce Toll-like receptor (TLR) signaling, such as bacterial capsular polysaccharides/lipopolysaccharide or single-stranded DNA containing unmethylated CpG oligodeoxynucleotides, activating TLR4 and TLR9, respectively. In addition to antigen-specific BCR signaling, signals mediated through innate receptors such as TLRs are crucial for the fine-tuning of B cell activation and function. Signals mediated through TLRs, in particular TLR7 and 9, have been shown to control the break of tolerance in B cell-mediated autoimmune diseases, such as systemic lupus erythematosus (SLE) (reviewed in [28]) and myasthenia gravis [29].

Survival of plasma cells depends on factors provided by their microenvironment, such as defined niches in the bone marrow [30] or in chronically inflamed organs [31], rather than on the type of signals which induce their activation and differentiation. Therefore, reaching those survival niches is a crucial prerequisite for a plasma cell in order to become long lived.

Memory B cells have been shown to be generated quite early in the immune responses, and the fact that a substantial fraction of memory $\mathrm{B}$ cells are actually $\operatorname{IgM}^{+}$and can be formed independent of germinal centers [32-34], together with findings that memory B cells are heterogeneous [35] has led to the concept that multiple layers of $B$ cell memory exist, probably reflecting a varying degree of plasticity and function within the compartment. 


\section{Mechanobiology of B cell activation}

While the biochemical changes during early B cell activation are well described, only recent advances in cellular imaging and biophysical techniques have allowed the analysis of the mechanobiological aspects of B cell activation [36,37]. As a result, recent studies have emphasized the importance of physical characteristics of ligand presentation, including mobility, density as well as the stiffness and topography of the presenting surface $[3,20-22,38,39]$ (see Fig. 1B).

Antigen binding to the BCR leads to conformational change, which facilitates an aggregation of the BCR in microclusters and recruitment of signaling intermediaries such as CD19 [37]. These initiate the formation and activation of the BCR-micro signalosome of downstream signaling pathways. Additionally, rapid spreading followed by contraction of the $\mathrm{B}$ cell on the antigen-presenting surface by actin cytoskeleton reorganization amplifies the initial response $[13,14,40]$.

Actin cytoskeleton plays a crucial role in the initiation of the B cell response. It controls lipid rafts, BCR diffusion, costimulatory (CD19, CD20) and inhibitory molecules (CD45, CD22, FcgRIIB) [37,41-43]. BCR-dependent actin cytoskeleton reorganization leads to cell spreading, formation of immune synapse and gathering of antigen for endocytosis [14]. In addition to the BCR-mediated actin reorganization, actin filaments exert reciprocal regulation on $\mathrm{BCR}$ signaling by controlling the access of kinases and phosphatases to their substrates [14,44]. For example, diffusion of the BCR is particularly slow in areas of dense actin network, and conversely, actin depolymerization increases BCR diffusion and microclustering $[45,46]$.

The importance of an intact actin cytoskeleton in B cells is most obvious in the case of Wiskott-Aldrich syndrome, which is caused by mutations in WAS. Encoding Wiskott-Aldrich syndrome protein (WASP), was shown to regulate actin polymerization in haematopoietic cells specifically $[47,48]$. Patients with WiskottAldrich syndrome suffer from bleedings and increased susceptibility to infections and cancer. Importantly, WASP defects reveal an important role of the actin cytoskeleton in B cell responses since the majority of patients suffer from B cell hyperactivity, which leads to antibody-mediated autoimmunity [49,50]. This suggests that cytoskeleton dynamics is closely interwoven with both the positive and negative regulation of $B$ cell activation [51].

The actin network in B cells drives the screening of antigen presenting surfaces. In the early stages after B cell spreading, transient activity of the Arp2/3 complex and formins creates a pattern of foci and fibers with special importance for antigen capture [14,52]. Further branched actin polymerization can generate protrusions by pushing the outer membrane or can participate in the invagination of the plasma membrane and antigen capture along with BCRdependent signaling and endocytic proteins [14,52] (see Fig. 1C). Lamellipodial protrusions generated by actin polymerization scan the APC surface by extending and retracting. During this process BCR microclusters gather antigen into the center of the IS within 10 mins after contact with an antigen-presenting surface [53]. A detailed study by Bolger-Munro et al. emphasized the importance of Arp2/3 and actin polymerization not only in the formation of BCR microclusters and downstream signaling but also in proliferation and survival of activated B cells [54].

\section{Substrate properties in B cell activation}

In vitro studies on flat surfaces have contributed greatly to our understanding of the mechanisms underlying B cell activation and signaling initiation [55]. However, cells encounter various antigenpresenting surfaces in vivo with different mechanical characteristics and topography [19]. As already mentioned above, B cells ei- ther encounter free antigens or antigens presented by different types of APCs.

For example, DCs have low cortical and membrane tension, and therefore their membranes pull out easily into long thin membrane protrusions/dendrites. These protrusions have viscous rather than elastic properties, which limits tension on the BCR [56,57]. To extract antigen from DCs, B cells pinch off part of the membrane through a trogocytic mechanism, without the need for separating the antigen from the membrane [40]. Consequently, B cells extract even low-affinity antigens from DCs [56]. By contrast, FDCs resist trogocytosis because of their high membrane and cytoskeletal tensions. To extract antigens presented by FDCs, B cells must use strong forces. This high mechanical resistance of FDCs promotes affinity discrimination by favoring high-affinity antigens [56]. As another mechanism subcapsular sinus (SCS) macrophages have been found to translocate captured viruses during early stages of infection across the SCS floor and further presenting them to follicular migrating $\mathrm{B}$ cells to initiate a humoral immune response [5].

Meanwhile it is clear that the BCR has a mechanosensing ability toward the antigen-presenting substrate that regulates molecular events during B cell activation $[19,20]$. These findings are supported by similar reports on T cell mechanosensing capability [5862], also in the context of their interaction with the APC [63].

A recent study by Ketchum et al. demonstrates clearly that surface topography regulates B cell actin dynamics and signaling $[19,21]$. They used parallel nanoridges with spacings of $3 \mu \mathrm{m}$ or greater to induce actin intensity oscillations that are consistent with actin polymerization waves. Nanotopography-induced actin dynamics required BCR signaling, actin polymerization, and myosin contractility. The topography of the stimulatory surface modulated the distribution of BCR clusters and intracellular calcium oscillations in activated B cells.

Stiffness shows the extent that an object resists deformation changes in response to an applied force. Young's modulus is used to describe the stiffness of an elastic substrate. For instance, stiffness of virus particles is about 45-1000 MPa [64,65], while most mammalian cells show stiffness features from 0.01 to $1000 \mathrm{kPa}$ [66]. Soluble antigens in our plasma only exhibit very low stiffness of maximum $100 \mathrm{~Pa}$ [67]. Moreover, the stiffness of the extracellular matrix (ECM) in tissues spans a broad range from $12 \mathrm{~Pa}$ to $20 \mathrm{kPa}$ on tissue level $[64,65,68]$, while single fibrin fibers show 1 - $15 \mathrm{MPa}$ [69], fibronectin fibers range from the low $\mathrm{kPa}$ range to few MPa [70]. For hematopoietic tissue it ranges from $0.3 \mathrm{kPa}$ in the central medullary region via the perivascular niche ( $3 \mathrm{kPa})$ to the endosteal region to be $340-50 \mathrm{kPa}$ there is a wide range of stiffnesses in order to maintain different sets of function for haematopoietic cells [71].

Shaheen et al. described that B cells depend on signaling molecules to be able to discriminate between different surface stiffness [19]. Protein kinase $C$ beta (PKC $\beta$ ) and focal adhesion kinase (FAK) were identified as signaling molecules that allow $\mathrm{B}$ cells to sense the substrate stiffness and respond accordingly $[19,72]$. B cells display a higher PKC $\beta$ dependent FAK activation when sensing a stiff substrate that translates into enhanced spreading and adhesion to the antigen-presenting substrate [19].

Another study by Zeng et al. used polydimethylsiloxane (PDMS) substrates with different stiffness (20 or $1100 \mathrm{kPa}$ ) to study B cell responses [20]. Interestingly, while stiffer substrates triggered stronger synaptic accumulation of BCR and phospho-Syk molecules compared with antigens on softer substrates, in vitro expansion of mouse primary B cells showed the opposite effects considering cell proliferation. Anti-CD40 antibodies enhance B cell proliferation on stiffer substrates, while specific antigens enhance B cell proliferation on softer substrates through a mechanism involving the enhanced phosphorylation of PI3K, Akt, and FoxO1. Addition- 
ally, softer substrates favored class switch differentiation of B cells in vitro and enhanced antibody response in vivo. As Fig. 1B summarizes, the different mechanical and topographical cues can be harvested to drive B-cell function and as we will see later has potentials for targeted immune therapies.

\section{B cells and tumor immunity}

There has been increasing interest in the role of B cells on disease mechanisms and immunotherapy. Recent studies have made important discoveries regarding the roles of B cells in different tumor types. The fact that B cells make up $25 \%$ of all cells in the tumor microenvironment [73] and up to $40 \%$ of the immune cells infiltrating the tumor $[74,75]$ in some types of cancer indicates that $B$ cells participate actively in the modulation of tumor immunity. Especially tumor-infiltrating B cells (TIBs), which directly infiltrate tumor tissue and modulate a complex immune response, have attracted attention [76]. B cells work by secreting antibodies and cytokines, processing and presenting antigens, and modulating $T$ cells and other immune cells [77].

B cells have multifaceted effects in antitumor response. While $\mathrm{T}$ lymphocytes and NK cells correlate with good prognosis in antitumor immunity, the addition of B cells shows the most beneficial prognostic value [78]. Tumor-infiltrating B cells have been associated with good prognosis and survival, increased treatment response, and increased antitumor efficacy in a variety of tumors such as esophageal and gastric cancer [78], ovarian cancer [79], cervical cancer [80], non-small cell lung cancer [81-83], squamous cell lung cancer [84], melanoma [85-87], sarcoma [88], renal cell cancer [89], and hepatocellular cancer [90].

Effective results have also been obtained in antitumor $\mathrm{T}$ cell immunity induced by CD40-activated B cells in preclinical cancer models and B cell-based cancer immunotherapy studies [91-94]. CD40-activated B cells are a powerful alternative to dendritic cells as professional APCs for immunotherapy and potentiate CD4 and CD8 T cell responses [95]. IL-12, which is secreted by B cells after activation with CD40, induces the production of IFN $\gamma$ by CD 4 $\mathrm{T}$ cells [96]. IFN $\gamma$ primarily activates macrophages, enhancing their phagocytosis and tumoricidal properties, and plays a critical role against tumors and viral, bacterial, and protozoal infections [97]. It also increases the antitumor and antiviral effects of CD8 T cells [98].

In non-small cell lung cancer patients, B cells are more concentrated in tumor tissue and adjacent tissues than other immune cells. With TIBs presenting tumor autoantigens, CD69+CD27+CD21+ TIBs (activated TIBs) lead antitumor CD4 $\mathrm{T}$ lymphocytes ( $\mathrm{T}$ helper cells) phenotype, while CD69-CD27CD21- TIBs trigger the formation of CD4 T cells (regulatory T cells) with the protumor effect. Thus, TIBs affect the type and function of CD4 T cells in tumor response [83]. When DCs, T cells, and B cells from cervical cancer patients are stimulated with anti-CD40 and IL4, an increase in the CD80+CD86+ $B$ cell population is observed. As tumor cells collected from cervical cancer patients and CD80+CD86 + B cells are injected into mice together, DCs induced tolerance, while B cells increased anti-tumor T cell responses [99].

Activated B cells themselves also show direct antitumor activity by secreting granzyme B and initiating antibody-mediated mechanisms $[100,101]$. While B cells differentiate into plasma cells with IL-21 stimulation simultaneously with CD40 ligand, with only IL21 stimulation they transform into cytotoxic B cells that secrete granzyme B and show direct antitumor activity [102]. Another antitumor activity of B cells is provided by Fas-FasL interaction. In vitro activated CD19+IL-10- B cells isolated from tumor-draining lymph nodes express FasL, which directly triggers apoptosis in 4T1 murine breast cancer cells expressing Fas [103].
Potent antitumor responses also occur in tertiary lymphoid structures (TLSs) which are ectopic lymphoid tissues that resemble secondary lymphoid organs, consist mainly of $\mathrm{T}$ and $\mathrm{B}$ cells and are formed directly in the tumor microenvironment [104]. There are mature and immature forms of TLS. In mature forms, an appropriate germinal center is formed, where B cell development and activation is ensured, while $T$ cells (and a smaller amount of mature DCs) surround this structure and show high antitumor activity. In immature TLS, a complete germinal center does not form and has low T cell activity [105]. B cells in immature TLSs show protumor properties with their inhibitory effects, while B cells in mature TLSs produce antibodies against the tumor and activate anti-tumor $\mathrm{T}$ cells by presenting tumor antigens [86-88]. The presence of $\mathrm{B}$ cells in TLSs in patients with metastatic melanoma, sarcoma, and renal cell carcinoma is associated with a high probability of success for immunotherapy, and the density of B cells and TLSs is higher in those who respond to immune checkpoint inhibition compared to non-responders [86-88]. Interestingly, this signature was more prominent than typical $\mathrm{T}$ cell signatures currently used for predicting immunotherapy outcomes. Due to these beneficial characteristics of TLSs and B cells in cancer immunotherapy, various methods such as cytokines, antibodies, chemokines, APCs, and synthetic biocompatible materials have been developed to trigger the formation of TLSs. A biomaterial scaffold combined with genetically manipulated DCs to express high gene expression for the different 12 chemokines associated with TLSs, when applied locally to the cancer-bearing host, works as a functional lymph node (bioengineered "designer lymph node") and triggers the anti-cancer immune response [106]. With regard to clinical implications of these studies, therapeutics to enhance $B$ cell responses should be prioritized as a complement to $\mathrm{T}$ cell-mediated immunotherapies. It opens the opportunity to introduce activated engineered $\mathrm{B}$ cells to target specific tumor antigens.

On the other side, some TIB subtypes release cytokines and different factors, causing inflammatory and angiogenic tumor microenvironment and contributing to the development of the tumor [101]. Vascular endothelial growth factor secreted by B cells increases blood flow and promotes tumor growth [107]. In nonsmall cell lung cancer, prostate cancer, and ovarian cancer, CD5+ $B$ cells have been associated with IL-6-mediated tumor progression [108]. On the other hand, regulatory B cells (B-reg) defined by secreting anti-inflammatory cytokines such as TGF- $\beta$ and IL10 , contribute to tumor metastasis [101]. Additionally, resting CD4 $\mathrm{T}$ cells turn into regulatory T cells via TGF- $\beta$ and IL-10 secreted by B-regs. In melanoma and sarcoma mouse models, tumor cells stimulate B cells to produce IL-10, which reduces the antitumor response by inhibiting the IFN- $\gamma$ secretion of cytotoxic T cells [109]. In the study conducted by Shalapour et al. in prostate cancer, it was found that $\mathrm{CD} 20+B$ cells transformed into plasma cells expressing immunoglobulin A (IgA), programmed death-ligand 1 (PDL1) and IL-10, depending on TGF- $\beta$ receptor signaling and most of the immune cells suppressing cytotoxic $\mathrm{T}$ cells and antitumor immunity were IgA+PD-L1+IL-10+ plasma cells. Elimination of these plasma cells increased the treatment response [110]. Another study demonstrated an IL-35-producing subpopulation of CD5+ B cells (CD1dhiCD5+) which accumulates in tumor tissue in pancreatic ductal adenocarcinoma and contributes to early tumor growth [111].

Although the presence of B cells in tumors has been associated with increased survival [112,113], there are reports of both antiand protumor roles for B cells [110]. These opposing reports reflect the various roles of $B$ cells in tumor responses. One key component of the antitumor function of B cells is B cell activation leading to release of tumor-specific antibodies or priming of $\mathrm{T}$ cells. However, B cells can produce inhibitory factors that block the antitumor immune response. Therefore, we engage in the discussion of 
Table 1

Stiffness alteration for tumor tissues. Usually showing tissue stiffening except for brain tumors, see text for more details.

\begin{tabular}{llll}
\hline & \multicolumn{2}{l}{ Stiffness [kPa] } & \\
\cline { 2 - 3 } & Cancer tissue & Healthy tissue & Reference \\
\hline Gastric cancer & $<7$ & $0.5-1$ & {$[120]$} \\
Ovarian cancer & 3 & 0.65 & {$[121]$} \\
Cervical cancer & 81 & 21 & {$[122]$} \\
Melanoma & 0.72 & 0.35 & {$[123]$} \\
Sarcoma & 2.4 & 0.7 & {$[124,125]$} \\
Breast cancer & $<4$ & 0.2 & {$[126,127]$} \\
Brain cancer & 1.3 & 1.5 & {$[128]$} \\
Colorectal cancer & 7.5 & 1 & {$[129]$} \\
\hline
\end{tabular}

both anti- and protumor effects of B cells emphasizing the importance of accumulating knowledge on targeted and optimal B cell activation.

Various evidence demonstrates that tumor-derived ECM is biochemically distinct in its composition compared with normal ECM [114]. Additionally to ECM, tumor stroma is typically reported to be stiffer than normal stroma ( $400 \mathrm{~Pa}$ compared with $150 \mathrm{~Pa}$, respectively), and that, for example, breast cancer tissue can be tenfold stiffer than normal breast tissue [115-117]. In Table 1 we have listed examples of tumor stiffness and their respective normal tissue. A stiffer tissue as is the case for most tumors, renders tumor infiltration more difficult (for review of the stiffness and resistance to treatment as well as the role of cell nucleus see $[118,119])$. The emerging role of B cells in tumor immunity and their mechanosensitivity discussed above highlights the importance of merging the accumulating knowledge in these research fields. More research is necessary to explore and optimize B cell tumor infiltration and function based on their altered mechanical properties.

\section{B cells in autoimmunity}

Next to the protective functions of B cells in the humoral as well as the cellular immune response, antibodies produced by $\mathrm{B}$ cells are widely used in preventive, therapeutic, diagnostic and research approaches. Yet, improperly activated B cells can engage in immunopathology such as autoimmunity. As B cells can have multiple roles in autoimmunity, such as (auto)antigen presentation [130], cytokine secretion [131], and, once they have differentiated into plasma cells, autoantibody secretion [132,133], their depletion is a promising therapeutic option. Thus, antibodies against B cellspecific epitopes can be applied as depleting agents to treat a variety of autoimmune diseases.

Because B cells secrete pro- and anti-inflammatory cytokines, they may have a role in disease pathogenesis as well as a protective effect against the disease. Pathogenic B cells obtained from mice with autoimmune encephalomyelitis, an experimental mouse model of multiple sclerosis (MS), secrete more IL-6 compared to naive control B cells. Disease severity was found to be lower in mice with B cell-specific IL-6 deficiency than those with wild-type $B$ cells. Therefore, in B cell depletion therapy for the treatment of autoimmune diseases, pathogenic B cells secreting IL-6 were targeted [134]. On the other hand, B cells also secrete IL-10, an antiinflammatory cytokine, and B-reg cells are distinguished primarily by secreting IL-10. The regulatory effect of IL-10 is to inhibit the pro-inflammatory immune response by inhibiting CD4 $T$ cell proliferation and reducing TH1 skewing [135]. Indeed, in autoimmune encephalomyelitis models, it was found that IL-10 was produced in healing mice, while the type 1 immune response persisted in mice with IL-10 deficiency, and no recovery was observed [136]. The anti-inflammatory cytokine of IL-35 is another negative regulator of immunity like IL-10. Similarly, T cell-mediated immune response and myelin destruction continue to increase in IL-35 de- ficient mice with autoimmune encephalomyelitis [137]. However, pro- and anti-inflammatory cytokines are secreted simultaneously in activated B cells and the balance between them is important in disease pathogenesis and hence in the treatment of autoimmune diseases like MS [138].

Most clinical data stem studies using antibodies targeting the transmembrane protein $\mathrm{CD} 20$ on the surface of $\mathrm{B}$ cells. It is expressed on all peripheral B cells, starting at the pre-B cell stage throughout maturity of the $\mathrm{B}$ cells, and it is also retained on memory B cells. The first anti-CD20 antibody, a chimeric mouse/human monoclonal antibody (Rituximab), which exerts its function by inducing antibody-dependent cell-mediated cytotoxicity, complement-dependent cytotoxicity, and also by direct induction of apoptosis [139], was initially developed for the treatment of non-Hodgkin Lymphoma and approved by the U.S. Food and Drug Administration in 1997 [140]. It subsequently gained approval for usage in rheumatoid arthritis and antibody-associated vasculitis. Clinical applications now also include off-label use in other autoimmune diseases, such as systemic sclerosis, Sjögren's syndrome, SLE [141], and pemphigus [142]. Clinical trials using antiCD20 therapy have marked a breakthrough for MS therapy, and although not formally approved for this indication, it has been routinely used to treat MS patients off-label [143-145]. Other antiCD20 antibodies have also been proven effective, and Ocrelizum$\mathrm{ab}$, a humanized antibody which targets a different, but overlapping epitope compared to Rituximab, was approved for MS treatment in 2017 (U.S.) and 2018 (Europe). Rituximab efficiently depletes peripheral B cells, reaching efficacies between $90 \%$ to $100 \%$. The reported time frames for $\mathrm{B}$ cell replenishment in the blood after anti-CD20 treatment vary between 6 and 21 months [146]. The clinical outcome of anti-CD20 treatment varies among autoimmune conditions, as well as on an individual patient basis, which may be explained by the fact that some B lineage cells do not express CD20, as discussed below.

CD19 represents another molecule on the surface of B cells, which can be targeted for therapeutic depletion [147]. Since CD19 expression in the B cell lineage starts earlier than that of CD20, and it is also expressed in a subset of plasma cells [148-150], it may have a broader effect on B lineage depletion than antibodies directed against CD20. In June 2020, Inebilizumab, a humanised anti-CD19 monoclonal antibody received approval in the U.S. for the treatment of neuromyelitis optica spectrum disorder in patients seropositive for immunoglobulin $G$ autoantibodies against aquaporin [151]. It is currently in clinical trials for myasthenia gravis, and IgG4-related disease and kidney transplant desensitization. Other approaches, under trials in B cell malignancies include bi-specific antibodies against CD19 and CD3 [152], the antibody drug conjugate coltuximab ravtansine, which consists of an antiCD19 monoclonal antibody conjugated to a potent cytotoxic maytansinoid [153], and anti-CD19 chimeric antigen receptor (CAR)expressing T cells [154].

Next to direct $\mathrm{B}$ cell targeting, a different strategy being pursued is the blockade of certain cytokines, which are crucial for the survival of B cells, in particular the TNF-family cytokines B cell activating factor (BAFF, also known as B Lymphocyte Stimulator, BLyS) and A proliferation inducing ligand (APRIL). Belimumab, a humanized anti-BAFF antibody, targets transitional, marginal zone, and naive B cells, and has been approved in the U.S. and E.U. for as add-on therapy for the treatment of adult patients with active, autoantibody-positive SLE [155]. Atacicept, which inhibits both BAFF and APRIL, was the subject of clinical trials with MS, however, those were suspended when some patients had an unexpected increase in inflammatory activity $[155,156]$. Taken together, all available studies highlight the heterogeneity of B cell subsets, which represents their various functions, a fact which has to be considered in therapeutic strategies. 
Plasma cells, terminally differentiated B cells which secrete antibodies, are one example for a therapy-resistant B cell subset, as they downregulate many molecules that are expressed on the surface of B cells, namely the B cell receptor [157], as well as CD20 [158]. A fraction of long lived plasma cells also discontinues CD19 expression CD19 [149,150]. Long lived plasma cells reside in the bone marrow [159] and have been shown to persist for decades in humans, providing the basis for protective humoral immunity [160]. Besides residing in their physiologic niches in bone marrow $[161,162]$ or gut lamina propria [163], long lived plasma cells can persist in chronically inflamed organs, and contribute to the continuous production of autoantibodies [164]. This has been shown for the kidneys of lupus mice $[132,165]$ and even the central nervous system under conditions of chronic neuroinflammation [31]. For the reasons mentioned above, rather than targeting surface molecules, approaches to target plasma cells aim at exploiting their most prominent feature, namely antibody production. The proteasome inhibitor Bortezomib, which is approved for the treatment of multiple myeloma, has been shown to efficiently depleted plasma cells, reduce autoantibody titers and ameliorate disease in a murine lupus model [166]. It has been used to treat SLE patients off-label [167], and recently it has been proven effective in therapy, refractory anti-NMDA-receptor encephalitis [168]. Other preclinical approaches include a selective targeting of antigen-specific plasma cells [169], and interfering with their metabolism [165].

\section{Conclusion and outlook}

Immunotherapy targets the immune system in the treatment of cancer, infection, or autoimmune diseases and involves the activation or suppression of specific immune cells. For this purpose, methods such as immunomodulators, immunosuppressive drugs, monoclonal antibodies, and adoptive cell therapies are constantly developing. Immunotherapy focuses largely on $\mathrm{T}$ cells, but there is a significant increase in the number of studies targeting additional immune cell types. Increasing evidence puts B cells at the forefront of immunotherapy. Properly activated B cells contribute to the immune response by secreting antigen-specific antibodies, pro- and anti-inflammatory cytokines and acting as APCs. They infiltrate tumor cells directly and show anti-cancer and anti-infective properties by using specific weapons such as granzyme B and specific antibodies. There is a significant accumulation of knowledge about the development, differentiation, migration, and relationship of $B$ cells with the microenvironment. In the increasing efforts to include B cells in novel immunotherapies, it is crucial to integrate this knowledge on both beneficial as well as pathological roles of B cells. Additionally, considering the large body of literature dedicated on the mechanobiology of the tumor microenvironment and the emerging key role of B cells in tumor immunity, it appears necessary to engage in studies dedicated particularly on the interaction of B cells and the tumor microenvironment. Together, combining and expanding our expertise on the potential of B cells including their mechanobiological properties will contribute greatly to newly emerging immunotherapies. We present this comprehensive review on B cell activation, mechanobiological properties, interaction with the environment, and current B cell-targeted therapeutic approaches to guide future studies on B cells and their clinical applications.

\section{Declaration of Competing Interest}

The authors declare that they have no known competing financial interests or personal relationships that could have appeared to influence the work reported in this paper.

\section{Acknowledgements}

DS acknowledges funding via SNF Spark. AEH thanks for funding from Deutsche Forschungsgemeinschaft (TRR130, project 17 and C01), and SFB1444, P14. EK thanks for financial support from Human Frontiers Science Program RGY0065/2017 and VW Stiftung Experiment! Grant 95664.

\section{References}

[1] N.A. Mitchison, T-cell-B-cell cooperation, Nat. Rev. Immunol. 4 (2004) 308-312.

[2] T.A. Barr, M. Gray, D. Gray, B cells: programmers of CD4 T cell responses, Infect. Disord. Drug Targets. 12 (2012) 222-231.

[3] M.F. Bachmann, G.T. Jennings, Vaccine delivery: a matter of size, geometry, kinetics and molecular patterns, Nat. Rev. Immunol. 10 (2010) 787-796.

[4] F. Sallusto, A. Lanzavecchia, K. Araki, R. Ahmed, From vaccines to memory and back, Immunity 33 (2010) 451-463, doi:10.1016/j.immuni.2010.10.008.

[5] T. Junt, E.A. Moseman, M. Iannacone, S. Massberg, P.A. Lang, M. Boes, K. Fink, S.E. Henrickson, D.M. Shayakhmetov, N.C. Di Paolo, N. van Rooijen, T.R. Mempel, S.P. Whelan, U.H. von Andrian, Subcapsular sinus macrophages in lymph nodes clear lymph-borne viruses and present them to antiviral B cells, Nature 450 (2007) 110-114

[6] M. Wykes, A. Pombo, C. Jenkins, G.G. MacPherson, Dendritic cells interact directly with naive $B$ lymphocytes to transfer antigen and initiate class switching in a primary T-dependent response, J. Immunol. 161 (1998) 1313-1319.

[7] H. Qi, Extrafollicular activation of lymph node B cells by antigen-bearing dendritic cells, Science 312 (2006) 1672-1676, doi:10.1126/science.1125703.

[8] A.K. Szakal, M.H. Kosco, J.G. Tew, A novel in vivo follicular dendritic cell-dependent iccosome-mediated mechanism for delivery of antigen to antigen-processing cells, J. Immunol. 140 (1988) 341-353.

[9] M. Bajénoff, R.N. Germain, B-cell follicle development remodels the conduit system and allows soluble antigen delivery to follicular dendritic cells, Blood 114 (2009) 4989-4997.

[10] K. Suzuki, I. Grigorova, T.G. Phan, L.M. Kelly, J.G. Cyster, Visualizing B cell capture of cognate antigen from follicular dendritic cells, J. Exp. Med. 206 (2009) 1485-1493.

[11] B.A. Heesters, M.C. Carroll, The role of dendritic cells in S. pneumoniae transport to follicular dendritic cells, Cell Rep 16 (2016) 3130-3137, doi:10.1016/j. celrep.2016.08.049

[12] F.D. Batista, M.S. Neuberger, B cells extract and present immobilized antigen: implications for affinity discrimination, EMBO J 19 (2000) 513-520.

[13] J. Li, W. Yin, Y. Jing, D. Kang, L. Yang, J. Cheng, Z. Yu, Z. Peng, X. Li, Y. Wen, X. Sun, B. Ren, C. Liu, The coordination between B cell receptor signaling and the actin cytoskeleton during B cell activation, Front Immunol 9 (2019), doi:10.3389/fimmu.2018.03096.

[14] P. Tolar, Cytoskeletal control of B cell responses to antigens, Nat. Rev. Immunol. 17 (2017) 621-634.

[15] F.D. Batista, D. Iber, M.S. Neuberger, B cells acquire antigen from target cells after synapse formation, Nature 411 (2001) 489-494

[16] K. Kläsener, P.C. Maity, E. Hobeika, J. Yang, M. Reth, B cell activation involves nanoscale receptor reorganizations and inside-out signaling by Syk, Elife. 3 (2014) e02069.

[17] G. Campi, R. Varma, M.L. Dustin, Actin and agonist MHC-peptide complex-dependent $\mathrm{T}$ cell receptor microclusters as scaffolds for signaling, J. Exp. Med. 202 (2005) 1031-1036.

[18] D. Depoil, S. Fleire, B.L. Treanor, M. Weber, N.E. Harwood, K.L. Marchbank, V.L.J. Tybulewicz, F.D. Batista, CD19 is essential for B cell activation by promoting B cell receptor-antigen microcluster formation in response to membrane-bound ligand, Nat. Immunol. 9 (2008) 63-72.

[19] S. Shaheen, Z. Wan, Z. Li, A. Chau, X. Li, S. Zhang, Y. Liu, J. Yi, Y. Zeng, J. Wang, X. Chen, L. Xu, W. Chen, F. Wang, Y. Lu, W. Zheng, Y. Shi, X. Sun, Z. Li, C. Xiong, W. Liu, Substrate stiffness governs the initiation of B cell activation by the concerted signaling of PKC $\beta$ and focal adhesion kinase, Elife 6 (2017), doi:10. 7554/eLife. 23060.

[20] Y. Zeng, J. Yi, Z. Wan, K. Liu, P. Song, A. Chau, F. Wang, Z. Chang, W. Han, W. Zheng, Y.-.H. Chen, C. Xiong, W. Liu, Substrate stiffness regulates B-cell activation, proliferation, class switch, and T-cell-independent antibody responses in vivo, Eur. J. Immunol. 45 (2015) 1621-1634.

[21] C.M. Ketchum, X. Sun, A. Suberi, J.T. Fourkas, W. Song, A. Upadhyaya, Subcellular topography modulates actin dynamics and signaling in B-cells, Mol. Biol. Cell. 29 (2018) 1732-1742.

[22] C. Ketchum, H. Miller, W. Song, A. Upadhyaya, Ligand mobility regulates B cell receptor clustering and signaling activation, Biophys. J. 106 (2014) 26-36.

[23] K.G. Smith, T.D. Hewitson, G.J. Nossal, D.M. Tarlinton, The phenotype and fate of the antibody-forming cells of the splenic foci, Eur. J. Immunol. 26 (1996) 444-448.

[24] Y. Zhang, L. Tech, L.A. George, A. Acs, R.E. Durrett, H. Hess, L.S.K. Walker, D.M. Tarlinton, A.L. Fletcher, A.E. Hauser, K.-M. Toellner, Plasma cell output from germinal centers is regulated by signals from Tfh and stromal cells, J. Exp. Med. 215 (2018) 1227-1243.

[25] A. Bortnick, I. Chernova, W.J. Quinn 3rd, M. Mugnier, M.P. Cancro, D. Allman, Long-lived bone marrow plasma cells are induced early in response 
to T cell-independent or T cell-dependent antigens, J. Immunol. 188 (2012) 5389-5396.

[26] J.B. Foote, T.I. Mahmoud, A.M. Vale, J.F. Kearney, Long-term maintenance of polysaccharide-specific antibodies by IgM-secreting cells, J. Immunol. 188 (2012) 57-67.

[27] M. Taillardet, G. Haffar, P. Mondière, M.-J. Asensio, H. Gheit, N. Burdin, T. Defrance, L. Genestier, The thymus-independent immunity conferred by a pneumococcal polysaccharide is mediated by long-lived plasma cells, Blood 114 (2009) 4432-4440

[28] S. Fillatreau, B. Manfroi, T. Dörner, Toll-like receptor signalling in B cells during systemic lupus erythematosus, Nat. Rev. Rheumatol. (2020), doi:10.1038/ s41584-020-00544-4.

[29] P. Cavalcante, C. Barzago, F. Baggi, C. Antozzi, L. Maggi, R. Mantegazza, P. Bernasconi, Toll-like receptors 7 and 9 in myasthenia gravis thymus: amplifiers of autoimmunity? Ann. N. Y. Acad. Sci. 1413 (2018) 11-24.

[30] K. Holzwarth, R. Köhler, L. Philipsen, K. Tokoyoda, V. Ladyhina, C. Wählby, R.A. Niesner, A.E. Hauser, Multiplexed fluorescence microscopy reveals heterogeneity among stromal cells in mouse bone marrow sections, Cytometry A 93 (2018) 876-888.

[31] K. Pollok, R. Mothes, C. Ulbricht, A. Liebheit, J.D. Gerken, S. Uhlmann, F. Paul, R. Niesner, H. Radbruch, A.E. Hauser, The chronically inflamed central nervous system provides niches for long-lived plasma cells, Acta Neuropathol Commun 5 (2017) 88.

[32] J.J. Taylor, K.A. Pape, M.K. Jenkins, A germinal center-independent pathway generates unswitched memory B cells early in the primary response, J. Exp. Med. 209 (2012) 597-606.

[33] K.A. Pape, J.J. Taylor, R.W. Maul, P.J. Gearhart, M.K. Jenkins, Different B cell populations mediate early and late memory during an endogenous immune response, Science 331 (2011) 1203-1207.

[34] H. Toyama, S. Okada, M. Hatano, Y. Takahashi, N. Takeda, H. Ichii, T. Takemori, Y. Kuroda, T. Tokuhisa, Memory B cells without somatic hypermutation are generated from Bcl6-deficient B cells, Immunity 17 (2002) 329-339.

[35] G.V. Zuccarino-Catania, S. Sadanand, F.J. Weisel, M.M. Tomayko, H. Meng, S.H. Kleinstein, K.L. Good-Jacobson, M.J. Shlomchik, CD80 and PD-L2 define functionally distinct memory B cell subsets that are independent of antibody isotype, Nat. Immunol. 15 (2014) 631-637.

[36] J. Boonyaratanakornkit, J.J. Taylor, Techniques to Study Antigen-Specific B Cell Responses, Front. Immunol. 10 (2019) 1694.

[37] N.E. Harwood, F.D. Batista, Visualizing the molecular and cellular events underlying the initiation of B-cell activation, Curr. Top. Microbiol. Immunol. 334 (2009) 153-177.

[38] M.F. Bachmann, U.H. Rohrer, T.M. Kündig, K. Bürki, H. Hengartner, R.M. Zinkernagel, The influence of antigen organization on B cell responsiveness, Science 262 (1993) 1448-1451.

[39] W. Liu, Z. Peng, Z. Liu, Y. Lu, J. Ding, Y.-H. Chen, High epitope density in a single recombinant protein molecule of the extracellular domain of influenza A virus M2 protein significantly enhances protective immunity, Vaccine 23 (2004) 366-371, doi:10.1016/j.vaccine.2004.05.028.

[40] E. Natkanski, W.-Y. Lee, B. Mistry, A. Casal, J.E. Molloy, P. Tolar, B cells use mechanical energy to discriminate antigen affinities, Science 340 (2013) 1587-1590.

[41] F. Gasparrini, C. Feest, A. Bruckbauer, PK. Mattila, J. Müller, L Nitschke, D. Bray, F.D. Batista, Nanoscale organization and dynamics of the siglec CD22 cooperate with the cytoskeleton in restraining BCR signalling, EMBO J 35 (2016) 258-280

[42] L. Xu, M. Xia, J. Guo, X. Sun, H. Li, C. Xu, X. Gu, H. Zhang, J. Yi, Y. Fang, H. Xie, J. Wang, Z. Shen, B. Xue, Y. Sun, T. Meckel, Y.-H. Chen, Z. Hu, Z. Li, C. Xu, H. Gong, W. Liu, Impairment on the lateral mobility induced by structural changes underlies the functional deficiency of the lupus-associated polymorphism Fc $\gamma$ RIIB-T232, J. Exp. Med. 213 (2016) 2707-2727, doi:10.1084/jem. 20160528.

[43] G. Pavlasova, M. Mraz, The regulation and function of CD20: an "enigma" of B-cell biology and targeted therapy, Haematologica 105 (2020) 1494-1506.

[44] K. Jaqaman, S. Grinstein, Regulation from within: the cytoskeleton in transmembrane signaling, Trends Cell Biol. 22 (2012) 515-526, doi:10.1016/j.tcb. 2012.07.006.

[45] B. Treanor, D. Depoil, A. Gonzalez-Granja, P. Barral, M. Weber, O. Dushek, A. Bruckbauer, F.D. Batista, The membrane skeleton controls diffusion dynamics and signaling through the B cell receptor, Immunity 32 (2010) 187-199, doi:10.1016/j.immuni.2009.12.005.

[46] S.J. Keppler, F. Gasparrini, M. Burbage, S. Aggarwal, B. Frederico, R.S. Geha, M. Way, A. Bruckbauer, F.D. Batista, Wiskott-Aldrich syndrome interacting protein deficiency uncovers the role of the Co-receptor CD19 as a generic hub for PI3 kinase signaling in B cells, Immunity 43 (2015) 660-673, doi:10.1016/ j.immuni.2015.09.004.

[47] J.M. Derry, H.D. Ochs, U. Francke, Isolation of a novel gene mutated in Wiskott-Aldrich syndrome, Cell 79 (1994) following 922.

[48] A.J. Thrasher, S.O. Burns, WASP: a key immunological multitasker, Nat. Rev. Immunol. 10 (2010) 182-192.

[49] A. Meyer-Bahlburg, S. Becker-Herman, S. Humblet-Baron, S. Khim, M. Weber, G. Bouma, A.J. Thrasher, F.D. Batista, D.J. Rawlings, Wiskott-Aldrich syndrome protein deficiency in B cells results in impaired peripheral homeostasis, Blood 112 (2008) 4158-4169, doi:10.1182/blood-2008-02-140814.

[50] S. Becker-Herman, A. Meyer-Bahlburg, M.A. Schwartz, S.W. Jackson, K.L. Hudkins, C. Liu, B.D. Sather, S. Khim, D. Liggitt, W. Song, G.J. Silverman,
C.E. Alpers, D.J. Rawlings, WASp-deficient B cells play a critical, cell-intrinsic role in triggering autoimmunity, J. Exp. Med. 208 (2011) 2033-2042.

[51] I. Rey-Suarez, B.A. Wheatley, P. Koo, A. Bhanja, Z. Shu, S. Mochrie, W. Song H. Shroff, A. Upadhyaya, WASP family proteins regulate the mobility of the B cell receptor during signaling activation, Nature Commun. (2020) 11, doi:10. 1038/s41467-020-14335-8.

[52] M. Bovellan, Y. Romeo, M. Biro, A. Boden, P. Chugh, A. Yonis, M. Vaghela, M. Fritzsche, D. Moulding, R. Thorogate, A. Jégou, A.J. Thrasher, G. Romet-Lemonne, P.P. Roux, E.K. Paluch, G. Charras, Cellular control of cortical actin nucleation, Curr. Biol. 24 (2014) 1628-1635.

[53] M. Fritzsche, C. Erlenkämper, E. Moeendarbary, G. Charras, K. Kruse, Actin kinetics shapes cortical network structure and mechanics, Sci Adv 2 (2016) e1501337.

[54] M. Bolger-Munro, K. Choi, J.M. Scurll, L. Abraham, R.S. Chappell, D. Sheen, M. Dang-Lawson, X. Wu, J.J. Priatel, D. Coombs, J.A. Hammer, M.R. Gold, Arp2/3 complex-driven spatial patterning of the BCR enhances immune synapse formation, BCR signaling and B cell activation, Elife 8 (2019), doi:10. 7554/eLife.44574.

[55] J.G. Cyster, C.D.C. Allen, B cell responses: cell interaction dynamics and decisions, Cell 177 (2019) 524-540.

[56] K.M. Spillane, P. Tolar, B cell antigen extraction is regulated by physical properties of antigen-presenting cells, J. Cell Biol. 216 (2017) 217230.

[57] I. Derényi, F. Jülicher, J. Prost, Formation and interaction of membrane tubes, Phys. Rev. Lett. 88 (2002), doi:10.1103/physrevlett.88.238101.

[58] E. Judokusumo, E. Tabdanov, S. Kumari, M.L. Dustin, L.C. Kam, Mechanosensing in T lymphocyte activation, Biophys. J. 102 (2012) L5-L7.

[59] M. Saitakis, S. Dogniaux, C. Goudot, N. Bufi, S. Asnacios, M. Maurin, C. Randriamampita, A. Asnacios, C. Hivroz, Different TCR-induced T lymphocyte responses are potentiated by stiffness with variable sensitivity, Elife 6 (2017), doi:10.7554/eLife.23190.

[60] K.P. Meng, F.S. Majedi, T.J. Thauland, M.J. Butte, Mechanosensing through YAP controls T cell activation and metabolism, J. Exp. Med. 217 (2020), doi:10. 1084/jem.20200053.

[61] D. Blumenthal, V. Chandra, L. Avery, J.K. Burkhardt, Mouse T cell priming is enhanced by maturation-dependent stiffening of the dendritic cell cortex, Elife 9 (2020), doi:10.7554/eLife.55995.

[62] E. Klotzsch, G.J. Schütz, Improved ligand discrimination by force-induced unbinding of the T cell receptor from peptide-MHC, Biophys. J. 104 (2013) 1670-1675.

[63] M. Aramesh, S. Mergenthal, M. Issler, B. Plochberger, F. Weber, X.-H. Qin, R. Liska, G.N. Duda, J.B. Huppa, J. Ries, G.J. Schütz, E. Klotzsch, Functionalized bead assay to measure three-dimensional traction forces during T-cell activation, Nano Lett. 21 (2021) 507-514.

[64] M.G. Mateu, Mechanical properties of viruses analyzed by atomic force microscopy: a virological perspective, Virus Res. 168 (2012) 1-22.

[65] G. Bao, S. Suresh, Cell and molecular mechanics of biological materials, Nature Mater. 2 (2003) 715-725, doi:10.1038/nmat1001.

[66] S. Nemir, J.L. West, Synthetic Materials in the Study of Cell Response to Substrate Rigidity, Ann. Biomed. Eng. 38 (2010) 2-20, doi:10.1007/ s10439-009-9811-1.

[67] G. de S. Araujo, F.L. Fonseca, B. Pontes, A. Torres, R.J.B. Cordero, R.M. Zancopé-Oliveira, A. Casadevall, N.B. Viana, L. Nimrichter, M.L. Rodrigues, E.S. Garcia, W. de Souza, S. Frases, Capsules from pathogenic and nonpathogenic Cryptococcus spp. manifest significant differences in structure and ability to protect against phagocytic cells, PLoS ONE 7 (2012) e29561.

[68] M.J. Paszek, N. Zahir, K.R. Johnson, J.N. Lakins, G.I. Rozenberg, A. Gefen, C.A. Reinhart-King, S.S. Margulies, M. Dembo, D. Boettiger, D.A. Hammer, V.M. Weaver, Tensional homeostasis and the malignant phenotype, Cancer Cell 8 (2005) 241-254.

[69] J.-P. Collet, H. Shuman, R.E. Ledger, S. Lee, J.W. Weisel, The elasticity of an individual fibrin fiber in a clot, Proc. Natl. Acad. Sci. U. S. A. 102 (2005) 9133-9137.

[70] E. Klotzsch, M.L. Smith, K.E. Kubow, S. Muntwyler, W.C. Little, F. Beyeler, D. Gourdon, B.J. Nelson, V. Vogel, Fibronectin forms the most extensible biological fibers displaying switchable force-exposed cryptic binding sites, Proc. Natl. Acad. Sci. U. S. A. 106 (2009) 18267-18272.

[71] P. Zhang, C. Zhang, J. Li, J. Han, X. Liu, H. Yang, The physical microenvironment of hematopoietic stem cells and its emerging roles in engineering applications, Stem Cell Res. Ther. 10 (2019) 327.

[72] C. Tsui, N. Martinez-Martin, M. Gaya, P. Maldonado, M. Llorian, N.M. Legrave, M. Rossi, J.I. MacRae, A.J. Cameron, P.J. Parker, M. Leitges, A. Bruckbauer, F.D. Batista, Protein kinase C- $\beta$ Dictates B cell fate by regulating mitochondrial remodeling, metabolic reprogramming, and heme biosynthesis, Immunity 48 (2018) 1144-1159.e5, doi:10.1016/j.immuni.2018.04.031.

[73] G.J. Yuen, E. Demissie, S. Pillai, B lymphocytes and cancer: a love-hate relationship, Trends Cancer Res. 2 (2016) 747-757.

[74] Y. Chin, J. Janseens, J. Vandepitte, J. Vandenbrande, L. Opdebeek, J. Raus, Phenotypic analysis of tumor-infiltrating lymphocytes from human breast cancer, Anticancer Res. 12 (1992) 1463-1466.

[75] B.H. Nelson, CD20+ B cells: the other tumor-infiltrating lymphocytes, J. Immunol. 185 (2010) 4977-4982.

[76] F.F. Guo, J.W. Cui, The role of tumor-infiltrating B cells in tumor immunity, J. Oncol. (2019) 2019.

[77] C. Mauri, A. Bosma, Immune regulatory function of B cells, Annu. Rev. Immunol. 30 (2012) 221-241. 
[78] M.C. Svensson, C. Fredrik Warfvinge, R. Fristedt, C. Hedner, D. Borg, J. Eberhard, P. Micke, B. Nodin, K. Leandersson, K. Jirström, The integrative clinical impact of tumor-infiltrating T lymphocytes and NK cells in relation to B lymphocyte and plasma cell density in esophageal and gastric adenocarcinoma, Oncotarget 8 (2017) https://www.oncotarget.com/article/19437/text/.

[79] J.S. Nielsen, R.A. Sahota, K. Milne, S.E. Kost, N.J. Nesslinger, P.H. Watson, B.H. Nelson, CD20+ tumor-infiltrating lymphocytes have an atypical CD27memory phenotype and together with CD8 $+\mathrm{T}$ cells promote favorable prognosis in ovarian cancer, Clin. Cancer Res. 18 (2012) 3281-3292.

[80] B.S. Nedergaard, M. Ladekarl, J.R. Nyengaard, K. Nielsen, A comparative study of the cellular immune response in patients with stage IB cervical squamous cell carcinoma. Low numbers of several immune cell subtypes are strongly associated with relapse of disease within 5 years, Gynecol. Oncol. 108 (2008) 106-111.

[81] M.P. Pelletier, M.D. Edwardes, R.P. Michel, F. Halwani, J.E. Morin, Prognostic markers in resectable non-small cell lung cancer: a multivariate analysis, Can. J. Surg. 44 (2001) 180-188.

[82] K.I. Al-Shibli, T. Donnem, S. Al-Saad, M. Persson, R.M. Bremnes, L.-T. Busund, Prognostic effect of epithelial and stromal lymphocyte infiltration in non-small cell lung cancer, Clin. Cancer Res. 14 (2008) 5220-5227.

[83] T.C. Bruno, Evaluating the antitumor role of B cells in patients with non-small cell lung cancer, J. Clin. Oncol. 35 (2017) 75-75.

[84] M. Mizukami, T. Hanagiri, Y. Shigematsu, T. Baba, T. Fukuyama, Y. Nagata, T. So, Y. Ichiki, M. Sugaya, M. Yasuda, T. So, M. Takenoyama, K. Sugio, K. Yasumoto, Effect of IgG produced by tumor-infiltrating B lymphocytes on lung tumor growth, Anticancer Res. 26 (2006) 1827-1831.

[85] D.J. DiLillo, K. Yanaba, T.F. Tedder, B cells are required for optimal CD4+ and CD8+ T cell tumor immunity: therapeutic B cell depletion enhances B16 melanoma growth in mice, J. Immunol. 184 (2010) 4006-4016.

[86] R. Cabrita, M. Lauss, A. Sanna, M. Donia, M. Skaarup Larsen, S. Mitra, I. Johansson, B. Phung, K. Harbst, J. Vallon-Christersson, A. van Schoiack, K. Lövgren, S. Warren, K. Jirström, H. Olsson, K. Pietras, C. Ingvar, K. Isaksson, D. Schadendorf, H. Schmidt, L. Bastholt, A. Carneiro, J.A. Wargo, I.M. Svane, G. Jönsson, Tertiary lymphoid structures improve immunotherapy and survival in melanoma, Nature 577 (2020) 561-565.

[87] B.A. Helmink, S.M. Reddy, J. Gao, S. Zhang, R. Basar, R. Thakur, K. Yizhak, M. Sade-Feldman, J. Blando, G. Han, V. Gopalakrishnan, Y. Xi, H. Zhao, R.N. Amaria, H.A. Tawbi, A.P. Cogdill, W. Liu, V.S. LeBleu, F.G. Kugeratski, S. Patel, M.A. Davies, P. Hwu, J.E. Lee, J.E. Gershenwald, A. Lucci, R. Arora, S. Woodman, E.Z. Keung, P.O. Gaudreau, A. Reuben, C.N. Spencer, E.M. Burton, L.E. Haydu, A.J. Lazar, R. Zapassodi, C.W. Hudgens, D.A. Ledesma, S. Ong, M. Bailey, S. Warren, D. Rao, O. Krijgsman, E.A. Rozeman, D. Peeper, C.U. Blank, T.N. Schumacher, L.H. Butterfield, M.A. Zelazowska, K.M. McBride, R. Kalluri, J. Allison, F. Petitprez, W.H. Fridman, C. Sautès-Fridman, N. Hacohen, K. Rezvani, P. Sharma, M.T. Tetzlaff, L. Wang, J.A. Wargo, B cells and tertiary lymphoid structures promote immunotherapy response, Nature 577 (2020) 549-555

[88] F. Petitprez, A. de Reyniès, E.Z. Keung, T.W.-W. Chen, C.-M. Sun, J. Calderaro, Y.-M. Jeng, L.-P. Hsiao, L. Lacroix, A. Bougoüin, M. Moreira, G. Lacroix, I. Natario, J. Adam, C. Lucchesi, Y. Laizet, M. Toulmonde, M.A. Burgess, V. Bolejack, D. Reinke, K.M. Wani, W.-L. Wang, A.J. Lazar, C.L. Roland, J.A. Wargo, A. Italiano, C. Sautès-Fridman, H.A. Tawbi, W.H. Fridman, B cells are associated with survival and immunotherapy response in sarcoma, Nature 577 (2020) $556-560$.

[89] J. DeFalco, M. Harbell, A. Manning-Bog, G. Baia, A. Scholz, B. Millare, M. Sumi, D. Zhang, F. Chu, C. Dowd, P. Zuno-Mitchell, D. Kim, Y. Leung, S. Jiang, X. Tang, K.S. Williamson, X. Chen, S.M. Carroll, G.Espiritu Santo, N. Haaser, N. Nguyen, E. Giladi, D. Minor, Y.C. Tan, J.B. Sokolove, L. Steinman, T.A. Serafini, G. Cavet, N.M. Greenberg, J. Glanville, W. Volkmuth, D.E. Emerling, W.H. Robinson, Non-progressing cancer patients have persistent B cell responses expressing shared antibody paratopes that target public tumor antigens, Clin. Immunol. 187 (2018) 37-45.

[90] S.M. Brunner, T. Itzel, C. Rubner, R. Kesselring, E. Griesshammer, M. Evert, A. Teufel, H.J. Schlitt, S. Fichtner-Feigl, Tumor-infiltrating B cells producing antitumor active immunoglobulins in resected HCC prolong patient survival, Oncotarget 8 (2017) https://www.oncotarget.com/article/20238/text/.

[91] M. von Bergwelt-Baildon, A. Shimabukuro-Vornhagen, A. Popov, N. KleinGonzalez, F. Fiore, S. Debey, A. Draube, B. Maecker, I. Menezes, L.M. Nadler, J.L. Schultze, CD40-activated B cells express full lymph node homing triad and induce T-cell chemotaxis: potential as cellular adjuvants, Blood 107 (2006) 2786-2789.

[92] R.S. Kornbluth, M. Stempniak, G.W. Stone, Design of CD40 agonists and their use in growing B cells for cancer immunotherapy, Int. Rev. Immunol. 31 (2012) 279-288.

[93] M. Mathieu, N. Cotta-Grand, J.F. Daudelin, S. Boulet, R. Lapointe, N. Labrecque, CD40-activated B cells can efficiently prime antigen-specific naïve CD8+ T cells to generate effector but not memory T cells, PLoS ONE 7 (2012) e30139.

[94] K. Wennhold, A. Shimabukuro-Vornhagen, M. von Bergwelt-Baildon, B cell-based cancer immunotherapy, Transfus. Med. Hemother. 46 (2019) 36-46.

[95] K. Wennhold, A. Shimabukuro-Vornhagen, S. Theurich, M. von Bergwelt-Baildon, CD40-activated B cells as antigen-presenting cells: the final sprint toward clinical application, Expert Rev. Vaccines. 12 (2013) 631-637.

[96] M. Wagner, H. Poeck, B. Jahrsdoerfer, S. Rothenfusser, D. Prell, B. Bohle, E. Tuma, T. Giese, J.W. Ellwart, S. Endres, G. Hartmann, IL-12p70-dependent Th1 induction by human B cells requires combined activation with CD40 ligand and CPG DNA, J. Immunol. 172 (2004) 954-963.
[97] J.R. Schoenborn, C.B. Wilson, Regulation of interferon- $\gamma$ during innate and adaptive immune responses, Adv. Immunol. 96 (2007) 41-101.

[98] P. Bhat, G. Leggatt, N. Waterhouse, I.H. Frazer, Interferon- $\gamma$ derived from cytotoxic lymphocytes directly enhances their motility and cytotoxicity, Cell Death Dis. 8 (2017) e2836.

[99] R.A.M. Rossetti, N.P.C. Lorenzi, K. Yokochi, M.B.S. de F. Rosa, L. Benevides, P.F.R. Margarido, E.C. Baracat, J.P. Carvalho, L.L. Villa, A.P. Lepique, B lymphocytes can be activated to act as antigen presenting cells to promote anti-tumor responses, PLoS ONE 13 (2018) e0199034.

[100] F.E. Lund, T.D. Randall, Effector and regulatory B cells: modulators of CD4+ T cell immunity, Nat. Rev. Immunol. 10 (2010) 236-247.

[101] P. Tsou, H. Katayama, E.J. Ostrin, S.M. Hanash, The emerging role of B cells in tumor immunity, Cancer Res. 76 (2016) 5597-5601.

[102] M. Hagn, K. Sontheimer, K. Dahlke, S. Brueggemann, C. Kaltenmeier, T. Beyer, S. Hofmann, O. Lunov, T. Barth, D. Fabricius, K. Tron, G. Nienhaus, T. Simmet, H. Schrezenmeier, B. Jahrsdörfer, Human B cells differentiate into granzyme B-secreting cytotoxic B lymphocytes upon incomplete T-cell help, Immunol. Cell Biol. 90 (2011) 457-467.

[103] H. Tao, L. Lu, Y. Xia, F. Dai, Y. Wang, Y. Bao, S.K. Lundy, F. Ito, Q. Pan, X. Zhang, F. Zheng, G. Shu, B. Fang, J. Jiang, J. Xia, S. Huang, Q. Li, A.E. Chang, Antitumor effector B cells directly kill tumor cells via the Fas/FasL pathway and are regulated by IL-10, Eur. J. Immunol. 45 (2015) 999-1009.

[104] M. Dieu-Nosjean, N.A. Giraldo, H. Kaplon, C. Germain, W.H. Fridman, C. Sautès-Fridman, Tertiary lymphoid structures, drivers of the anti-tumor responses in human cancers, Immunol. Rev. 271 (2016) 260-275.

[105] C. Sautès-Fridman, F. Petitprez, J. Calderaro, W.H. Fridman, Tertiary lymphoid structures in the era of cancer immunotherapy, Nat. Rev. Cancer. 19 (2019) 307-325.

[106] G. Zhu, R. Falahat, K. Wang, A. Mailloux, N. Artzi, J.J. Mulé, Tumor-associated tertiary lymphoid structures: gene-expression profiling and their bioengineering, Front. Immunol. 8 (2017) 767.

[107] G. Neufeld, O. Kessler, Pro-angiogenic cytokines and their role in tumor angiogenesis, Cancer Metastasis Rev 25 (2006) 373-385.

[108] C. Zhang, H. Xin, W. Zhang, P.J. Yazaki, Z. Zhang, K. Le, W. Li, H. Lee, L. Kwak, S. Forman, CD5 binds to interleukin-6 and induces a feed-forward loop with the transcription factor STAT3 in B cells to promote cancer, Immunity 44 (2016) 913-923.

[109] S. Inoue, W.W. Leitner, B. Golding, D. Scott, Inhibitory effects of B cells on antitumor immunity, Cancer Res 66 (2006) 7741-7747.

[110] S. Shalapour, J. Font-Burgada, G. Di Caro, Z. Zhong, E. Sanchez-Lopez, D. Dhar, G. Willimsky, M. Ammirante, A. Strasner, D.E. Hansel, C. Jamieson, C.J. Kane, T. Klatte, P. Birner, L. Kenner, M. Karin, Immunosuppressive plasma cells impede T-cell-dependent immunogenic chemotherapy, Nature 521 (2015) 94-98.

[111] Y. Pylayeva-Gupta, S. Das, J.S. Handler, C.H. Hajdu, M. Coffre, S.B. Koralov, D. Bar-Sagi, IL35-producing B cells promote the development of pancreatic neoplasia, Cancer Discov 6 (2016) 247-255.

[112] A. Shimabukuro-Vornhagen, H.A. Schlößer, L. Gryschok, J. Malcher, K. Wennhold, M. Garcia-Marquez, T. Herbold, L.S. Neuhaus, H.J. Becker, A. Fiedler, P. Scherwitz, T. Koslowsky, R. Hake, D.L. Stippel, A.H. Hölscher, S. Eidt, M. Hallek, S. Theurich, M.S. von Bergwelt-Baildon, Characterization of tumor-associated B-cell subsets in patients with colorectal cancer, Oncotarget 5 (2014) 4651-4664.

[113] C. Germain, S. Gnjatic, F. Tamzalit, S. Knockaert, R. Remark, J. Goc, A. Lepelley, E. Becht, S. Katsahian, G. Bizouard, P. Validire, D. Damotte, M. Alifano, P. Magdeleinat, I. Cremer, J.-L. Teillaud, W.-H. Fridman, C. Sautès-Fridman, M.-C. Dieu-Nosjean, Presence of B cells in tertiary lymphoid structures is associated with a protective immunity in patients with lung cancer, Am. J. Respir. Crit. Care Med. 189 (2014) 832-844.

[114] T.R. Cox, J.T. Erler, Remodeling and homeostasis of the extracellular matrix: implications for fibrotic diseases and cancer, Dis. Model. Mech. 4 (2011) $165-178$.

[115] L. Kass, J.T. Erler, M. Dembo, V.M. Weaver, Mammary epithelial cell: influence of extracellular matrix composition and organization during development and tumorigenesis, Int. J. Biochem. Cell Biol. 39 (2007) 1987-1994.

[116] D.T. Butcher, T. Alliston, V.M. Weaver, A tense situation: forcing tumour progression, Nat. Rev. Cancer. 9 (2009) 108-122.

[117] Q.-T. Le, J. Harris, A.M. Magliocco, C.S. Kong, R. Diaz, B. Shin, H. Cao, A. Trotti, J.T. Erler, C.H. Chung, A. Dicker, T.F. Pajak, A.J. Giaccia, K.K. Ang, Validation of lysyl oxidase as a prognostic marker for metastasis and survival in head and neck squamous cell carcinoma: radiation Therapy Oncology Group trial 90-03, J. Clin. Oncol. 27 (2009) 4281-4286.

[118] S.S. Deville, N. Cordes, The Extracellular, Cellular, and Nuclear Stiffness, a Trinity in the Cancer Resistome-A Review, Front. Oncol. 9 (2019) 1376.

[119] F. Spill, C. Bakal, M. Mak, Mechanical and Systems Biology of Cancer, Comput. Struct. Biotechnol. J. 16 (2018) 237-245.

[120] M. Jang, J. An, S.W. Oh, J.Y. Lim, J. Kim, J.K. Choi, J.-H. Cheong, P. Kim, Matrix stiffness epigenetically regulates the oncogenic activation of the Yes-associated protein in gastric cancer, Nat Biomed Eng 5 (2021) 114-123.

[121] E.I. Harper, E.F. Sheedy, M.S. Stack, With Great Age Comes Great Metastatic Ability: ovarian Cancer and the Appeal of the Aging Peritoneal Microenvironment, Cancers (Basel) 10 (2018), doi:10.3390/cancers10070230.

[122] Y. Cui, X. Zhang, K. You, Y. Guo, C. Liu, X. Fang, L. Geng, Nanomechanical Characteristics of Cervical Cancer and Cervical Intraepithelial Neoplasia Revealed by Atomic Force Microscopy, Med. Sci. Monit. 23 (2017) 4205-4213.

[123] T. Watanabe, H. Kuramochi, A. Takahashi, K. Imai, N. Katsuta, T. Nakayama 
H. Fujiki, M. Suganuma, Higher cell stiffness indicating lower metastatic potential in B16 melanoma cell variants and in (-)-epigallocatechin gallate-treated cells, J. Cancer Res. Clin. Oncol. 138 (2012) 859-866.

[124] K. Pepin, R. Grimm, S. Kargar, B.M. Howe, K. Fritchie, M. Frick, D. Wenger, S. Okuno, R. Ehman, K. McGee, S. James, N. Laack, M. Herman, D. Pafundi, Soft Tissue Sarcoma Stiffness and Perfusion Evaluation by MRE and DCE-MRI for Radiation Therapy Response Assessment: a Technical Feasibility Study, Biomed Phys Eng Express 5 (2019), doi:10.1088/2057-1976/ab2175.

[125] K.R. Levental, H. Yu, L. Kass, J.N. Lakins, M. Egeblad, J.T. Erler, S.F.T. Fong, K. Csiszar, A. Giaccia, W. Weninger, M. Yamauchi, D.L. Gasser, V.M. Weaver, Matrix crosslinking forces tumor progression by enhancing integrin signaling, Cell 139 (2009) 891-906.

[126] K.R. Levental, H. Yu, L. Kass, J.N. Lakins, M. Egeblad, J.T. Erler, S.F.T. Fong, K. Csiszar, A. Giaccia, W. Weninger, M. Yamauchi, D.L. Gasser, V.M. Weaver, Matrix crosslinking forces tumor progression by enhancing integrin signaling, Cell 139 (2009) 891-906.

[127] S. Azadi, M. Tafazzoli-Shadpour, M. Soleimani, M.E. Warkiani, Modulating cancer cell mechanics and actin cytoskeleton structure by chemical and mechanical stimulations, J. Biomed. Mater. Res. A. 107 (2019) 1569-1581.

[128] A. Bunevicius, K. Schregel, R. Sinkus, A. Golby, S. Patz, REVIEW: MR elastography of brain tumors, Neuroimage Clin 25 (2020) 102109.

[129] S. Kawano, M. Kojima, Y. Higuchi, M. Sugimoto, K. Ikeda, N. Sakuyama, S. Takahashi, R. Hayashi, A. Ochiai, N. Saito, Assessment of elasticity of colorectal cancer tissue, clinical utility, pathological and phenotypical relevance, Cancer Sci 106 (2015) 1232-1239.

[130] A. Crawford, M. MacLeod, T. Schumacher, L. Corlett, D. Gray, Primary T Cell Expansion and Differentiation In Vivo Requires Antigen Presentation by B Cells, The Journal of Immunology 176 (2006) 3498-3506, doi:10.4049/ jimmunol.176.6.3498

[131] A.C. Lino, T. Dörner, A. Bar-Or, S. Fillatreau, Cytokine-producing B cells: a translational view on their roles in human and mouse autoimmune diseases, Immunol. Rev. 269 (2016) 130-144

[132] G. Cassese, S. Lindenau, B. de Boer, S. Arce, A. Hauser, G. Riemekasten, C. Berek, F. Hiepe, V. Krenn, A. Radbruch, R.A. Manz, Inflamed kidneys of NZB/W mice are a major site for the homeostasis of plasma cells, Eur. J. Immunol. 31 (2001) 2726-2732 3.0.co;2-h.">10.1002/1521-4141(200109)31:9<2726::aid--immu2726>3.0.co;2 - h.

[133] Q. Cheng, I.M. Mumtaz, L. Khodadadi, A. Radbruch, B.F. Hoyer, F. Hiepe, Autoantibodies from long-lived "memory" plasma cells of NZB/W mice drive immune complex nephritis, Ann. Rheum. Dis. 72 (2013) 2011-2017.

[134] T.A. Barr, P. Shen, S. Brown, V. Lampropoulou, T. Roch, S. Lawrie, B. Fan, R.A. O'Connor, S.M. Anderton, A. Bar-Or, S. Fillatreau, D. Gray, B cell depletion therapy ameliorates autoimmune disease through ablation of IL-6-producing B cells, J. Exp. Med. 209 (2012) 1001-1010.

[135] L.C. Lighaam, P.-P.A. Unger, D.W. Vredevoogd, D. Verhoeven, E. Vermeulen, A.W. Turksma, A. Ten Brinke, T. Rispens, S.M. van Ham, Induced Human IL-10 B Cells Do Not Show a Subset-Defining Marker Signature and Plastically Coexpress IL-10 With Pro-Inflammatory Cytokines, Front. Immunol. 9 (2018) 1913.

[136] S. Fillatreau, C.H. Sweenie, M.J. McGeachy, D. Gray, S.M. Anderton, B cells regulate autoimmunity by provision of IL-10, Nat. Immunol. 3 (2002) 944-950.

[137] P. Shen, T. Roch, V. Lampropoulou, R.A. O'Connor, U. Stervbo, E. Hilgenberg, S. Ries, V.D. Dang, Y. Jaimes, C. Daridon, R. Li, L. Jouneau, P. Boudinot, S. Wilantri, I. Sakwa, Y. Miyazaki, M.D. Leech, R.C. McPherson, S. Wirtz, M. Neurath, K. Hoehlig, E. Meinl, A. Grützkau, J.R. Grün, K. Horn, A.A. Kühl, T. Dörner, A. Bar-Or, S.H.E. Kaufmann, S.M. Anderton, S. Fillatreau, IL-35producing B cells are critical regulators of immunity during autoimmune and infectious diseases, Nature 507 (2014) 366-370, doi:10.1038/nature12979.

[138] R. Li, A. Rezk, L.M. Healy, G. Muirhead, A. Prat, J.L. Gommerman, A. Bar-Or, MSSRF Canadian B cells in MS Team, Cytokine-Defined B Cell Responses as Therapeutic Targets in Multiple Sclerosis, Front. Immunol. 6 (2015) 626.

[139] P.J. Mease, B cell-targeted therapy in autoimmune disease: rationale, mechanisms, and clinical application, J. Rheumatol. 35 (2008) 1245-1255.

[140] C. Jonas, Rituxan: the new kid on the block, Oncol. Nurs. Forum. 25 (1998) 669

[141] T. Schioppo, F. Ingegnoli, Current perspective on rituximab in rheumatic diseases, Drug Des. Devel. Ther. 11 (2017) 2891-2904.

[142] P. Joly, H. Mouquet, J.-C. Roujeau, M. D'Incan, D. Gilbert, S. Jacquot, M.-L. Gougeon, C. Bedane, R. Muller, B. Dreno, M.-.S. Doutre, E. Delaporte, C. Pauwels, N. Franck, F. Caux, C. Picard, E. Tancrede-Bohin, P. Bernard, F. Tron, M. Hertl, P. Musette, A single cycle of rituximab for the treatment of severe pemphigus, N. Engl. J. Med. 357 (2007) 545-552.

[143] S.L. Hauser, E. Waubant, D.L. Arnold, T. Vollmer, J. Antel, R.J. Fox, A. Bar-Or, M. Panzara, N. Sarkar, S. Agarwal, A. Langer-Gould, C.H. Smith, B-Cell Depletion with Rituximab in Relapsing-Remitting Multiple Sclerosis, New Engl. J. Med. 358 (2008) 676-688, doi:10.1056/nejmoa0706383.

[144] A. Bar-Or, P.A.J. Calabresi, D. Arnold, C. Markowitz, S. Shafer, L.H. Kasper, E. Waubant, S. Gazda, R.J. Fox, M. Panzara, N. Sarkar, S. Agarwal, C.H. Smith, Rituximab in relapsing-remitting multiple sclerosis: a 72-week, open-label, phase I trial, Ann. Neurol. 63 (2008) 395-400.

[145] J. Salzer, R. Svenningsson, P. Alping, L. Novakova, A. Björck, K. Fink, P. IslamJakobsson, C. Malmeström, M. Axelsson, M. Vågberg, P. Sundström, J. Lycke, F. Piehl, A. Svenningsson, Rituximab in multiple sclerosis: a retrospective observational study on safety and efficacy, Neurology 87 (2016) 2074-2081.

[146] G. Cambridge, M.J. Leandro, J.C.W. Edwards, M.R. Ehrenstein, M. Salden,
M. Bodman-Smith, A.D.B. Webster, Serologic changes following B lymphocyte depletion therapy for rheumatoid arthritis, Arthritis Rheum 48 (2003) 2146-2154.

[147] T.F. Tedder, CD19: a promising B cell target for rheumatoid arthritis, Nat. Rev. Rheumatol. 5 (2009) 572-577.

[148] S. Arce, E. Luger, G. Muehlinghaus, G. Cassese, A. Hauser, A. Horst, K. Lehnert, M. Odendahl, D. Hönemann, K.-D. Heller, H. Kleinschmidt, C. Berek, T. Dörner, V. Krenn, F. Hiepe, R. Bargou, A. Radbruch, R.A. Manz, CD38 low IgG-secreting cells are precursors of various CD38 high-expressing plasma cell populations, J. Leukoc. Biol. 75 (2004) 1022-1028.

[149] H.E. Mei, I. Wirries, D. Frölich, M. Brisslert, C. Giesecke, J.R. Grün, T. Alexander, S. Schmidt, K. Luda, A.A. Kühl, R. Engelmann, M. Dürr, T. Scheel, M. Bokarewa, C. Perka, A. Radbruch, T. Dörner, A unique population of IgG-expressing plasma cells lacking CD19 is enriched in human bone marrow, Blood 125 (2015) 1739-1748.

[150] J.L. Halliley, C.M. Tipton, J. Liesveld, A.F. Rosenberg, J. Darce, I.V. Gregoretti, L. Popova, D. Kaminiski, C.F. Fucile, I. Albizua, S. Kyu, K.-Y. Chiang, K.T. Bradley, R. Burack, M. Slifka, E. Hammarlund, H. Wu, L. Zhao, E.E. Walsh, A.R. Falsey, T.D. Randall, W.C. Cheung, I. Sanz, F.E.-H. Lee, Long-Lived Plasma Cells Are Contained within the CD19(-)CD38(hi)CD138(+) Subset in Human Bone Marrow, Immunity 43 (2015) 132-145.

[151] J.E. Frampton, Inebilizumab: first Approval, Drugs 80 (2020) 1259-1264.

[152] A. Viardot, F. Locatelli, J. Stieglmaier, F. Zaman, E. Jabbour, Concepts in immuno-oncology: tackling B cell malignancies with CD19-directed bispecific T cell engager therapies, Ann. Hematol. 99 (2020) 2215-2229.

[153] B. Coiffier, C. Thieblemont, S. de Guibert, J. Dupuis, V. Ribrag, R. Bouabdallah, F. Morschhauser, R. Navarro, S.Le Gouill, C. Haioun, R. Houot, O. Casasnovas, H. Holte, T. Lamy, F. Broussais, S. Payrard, L. Hatteville, H. Tilly, A phase II, single-arm, multicentre study of coltuximab ravtansine (SAR3419) and rituximab in patients with relapsed or refractory diffuse large B-cell lymphoma, Br. J. Haematol. 173 (2016) 722-730, doi:10.1111/bjh.13992.

[154] J.N. Brudno, N. Lam, D. Vanasse, Y.-W. Shen, J.J. Rose, J. Rossi, A. Xue, A. Bot, N. Scholler, L. Mikkilineni, M. Roschewski, R. Dean, R. Cachau, P. Youkharibache, R. Patel, B. Hansen, D.F. Stroncek, S.A. Rosenberg, R.E. Gress, J.N. Kochenderfer, Safety and feasibility of anti-CD19 CAR T cells with fully human binding domains in patients with B-cell lymphoma, Nat. Med. 26 (2020) 270-280, doi:10.1038/s41591-019-0737-3.

[155] H.A. Blair, S.T. Duggan, Belimumab: a Review in Systemic Lupus Erythematosus, Drugs 78 (2018) 355-366, doi:10.1007/s40265-018-0872-z.

[156] D. Baker, G. Pryce, L.K. James, K. Schmierer, G. Giovannoni, Failed B cell survival factor trials support the importance of memory B cells in multiple sclerosis, Eur. J. Neurol. 27 (2020) 221-228, doi:10.1111/ene.14105.

[157] R.A. Manz, G. Cassese, A. Thiel, A. Radbruch, Long-lived plasma cells survive independent of antigen, Curr. Top. Microbiol. Immunol. 246 (1999) 71-74 discussion 74-5.

[158] F. Hiepe, T. Dörner, A.E. Hauser, B.F. Hoyer, H. Mei, A. Radbruch, Long-lived autoreactive plasma cells drive persistent autoimmune inflammation, Nat. Rev. Rheumatol. 7 (2011) 170-178.

[159] R.A. Manz, A. Thiel, A. Radbruch, Lifetime of plasma cells in the bone marrow, Nature 388 (1997) 133-134, doi:10.1038/40540.

[160] I.J. Amanna, N.E. Carlson, M.K. Slifka, Duration of humoral immunity to common viral and vaccine antigens, N. Engl. J. Med. 357 (2007) 1903-1915.

[161] K. Roth, L. Oehme, S. Zehentmeier, Y. Zhang, R. Niesner, A.E. Hauser, Tracking plasma cell differentiation and survival, Cytometry A 85 (2014) 15-24.

[162] S. Zehentmeier, K. Roth, Z. Cseresnyes, Ö. Sercan, K. Horn, R.A. Niesner, H.D. Chang, A. Radbruch, A.E. Hauser, Static and dynamic components synergize to form a stable survival niche for bone marrow plasma cells, Eur. J. Immunol. 44 (2014) 2306-2317, doi:10.1002/eji.201344313.

[163] A. Lemke, M. Kraft, K. Roth, R. Riedel, D. Lammerding, A.E. Hauser, Long-lived plasma cells are generated in mucosal immune responses and contribute to the bone marrow plasma cell pool in mice, Mucosal Immunol. 9 (2016) 83-97.

[164] B.F. Hoyer, K. Moser, A.E. Hauser, A. Peddinghaus, C. Voigt, D. Eilat, A. Radbruch, F. Hiepe, R.A. Manz, Short-lived plasmablasts and long-lived plasma cells contribute to chronic humoral autoimmunity in NZB/W mice, J. Exp. Med. 199 (2004) 1577-1584.

[165] D.D. Jones, B.T. Gaudette, J.R. Wilmore, I. Chernova, A. Bortnick, B.M. Weiss, D. Allman, mTOR has distinct functions in generating versus sustaining humoral immunity, J. Clin. Invest. 126 (2016) 4250-4261.

[166] K. Neubert, S. Meister, K. Moser, F. Weisel, D. Maseda, K. Amann, C. Wiethe, T.H. Winkler, J.R. Kalden, R.A. Manz, R.E. Voll, The proteasome inhibitor bortezomib depletes plasma cells and protects mice with lupus-like disease from nephritis, Nat. Med. 14 (2008) 748-755.

[167] T. Alexander, R. Sarfert, J. Klotsche, A.A. Kühl, A. Rubbert-Roth, H.-M. Lorenz, J. Rech, B.F. Hoyer, Q. Cheng, A. Waka, A. Taddeo, M. Wiesener, G. Schett, G.-R. Burmester, A. Radbruch, F. Hiepe, R.E. Voll, The proteasome inhibitior bortezomib depletes plasma cells and ameliorates clinical manifestations of refractory systemic lupus erythematosus, Ann. Rheum. Dis. 74 (2015) 1474-1478.

[168] F. Scheibe, H. Prüss, A.M. Mengel, S. Kohler, A. Nümann, M. Köhnlein, K. Ruprecht, T. Alexander, F. Hiepe, A. Meisel, Bortezomib for treatment of therapy-refractory anti-NMDA receptor encephalitis, Neurology 88 (2017) 366-370.

[169] A. Taddeo, V. Gerl, B.F. Hoyer, H.-D. Chang, S. Kohler, H. Schaffert, A. Thiel, A. Radbruch, F. Hiepe, Selection and depletion of plasma cells based on the specificity of the secreted antibody, Eur. J. Immunol. 45 (2015) 317-319. 